\title{
RESILIENSI DAN NEED FOR ACHIEVEMENT PADA REGU PASKIBRAKA DI SMA ISLAM MALANG
}

\author{
Fitri Mandasari, Sri Wiworo Retno Indah Handayani \\ Fakultas Psikologi Universitas Wisnuwardhana Malang \\ V3mandasari@gmail.com
}

\begin{abstract}
Abstrak: Tujuan penelitian ini untuk mengetahui apakah ada hubungan antara resiliensi dan need for achievement pada Regu Paskibraka di SMA Islam Malang. Metode yang digunakan pada penelitian ini yaitu kuantitatif. Populasi yang digunakan berjumlah 50 siswa dan teknik pengumpulan data yang digunakan adalah studi populasi. Hasil yang telah diperoleh dengan menggunakan analisis Product Moment diketahui hasil signifikansi 0,466 > 0,05, yang artinya tidak ada hubungan antara resiliensi dengan need for achievement pada Regu Paskibraka di SMA Islam Malang. Menggunakan taraf kepercayaan 95\% dengan demikian hipotesa ditolak. Mereka kurang fokus pada keinginan untuk berprestasi, yang penting adalah tugas selesai walau tidak memuaskan.
\end{abstract}

Kata kunci: resiliensi; need for achievement; Paskibraka

Abstract: The purpose of this study was to determine whether there was a relationship between resilience and need for achievement in the Paskibraka Team at Malang Islamic High School. The method used in this study is quantitative. The population used amounted to 50 students and the data collection techniques used were population studies. The results that have been obtained using Product Moment analysis are known to have a significance result of $0.466>0.05$, which means that there is no relationship between resilience and the need for achievement in the Paskibraka Team in Malang Islamic High School. Using the 95\% confidence level thus the hypothesis is rejected. They are less focused on the desire to achieve, the important thing is the task is finished even though it is not satisfying.

Keywords: resiliensi; need for achievement;Paskibraka

\section{PENDAHULUAN}

Permasalahan dan tantangan serta kesulitan merupakan fenomena hidup yang tidak bisa dihindari. Reaksi setiap individu terhadap berbagai tantangan atau permasalahan dalam hidup ternyata berbeda-beda. Perbedaan reaksi ini ternyata disebabkan oleh cara pandang yang berbeda terhadap permasalahan yang ada. Pada usia 17-21 tahun disebut dengan perkembangan remaja lanjut, yang selalu ingin menjadi pusat perhatian, emosi tidak stabil serta mempunyai cita-cita dan semangat yang tinggi.

Sama halnya dengan siswa SMA, dimana mereka yang baru masuk ke jenjang ini harus bisa menyesuaikan diri dengan lingkungan yang baru, dengan teman yang baru, dan metode pembelajaran yang baru. Sehingga beberapa dari mereka mengalami kesulitan dalam pembelajaran akademis maupun non akademis. Mereka yang dapat menyesuaikan iri dengan cepat dan dapat menyelesaikan suatu masalahnya sendiri akan dapat bergerak maju dari pada mereka yang tidak bisa menyelesaikan masalahnya dan kabur ke hal-hal yang negatif.

Akhirnya, banyak siswa yang hanya puas dengan mendapat nilai yang baik dari mata pelajaran yang mereka sukai saja. Mereka tidak memiliki motivasi untuk lebih 
tinggi dari kemampuan yang ada, hal ini terus mengacu terhadap need for achievement atau yang biasa disebut motivasi berprestasi.

Tri Mardiana, Daviq Chairilsyah dan Devi Risma (2015), menyatakan bahwa berdasarkan hasil uji hipotesis yang diperoleh terdapat hubungan yang positif dan signifikan antara self resiliensi dengan motivasi berprestasi PG PAUD fakultas keguruan dan ilmu pendidikan universitas Riau. Dikatakan positif karena jika resiliensi naik atau tinggi maka motivasi berprestasi juga ikut naik atau tinggi.

Siswa membutuhkan fasilitas-fasilitas yang dapat memudahkan kegiatan mereka dalam pengerjaan tugas seperti laptop, buku panduan dan alat tulis, wifi sebagai alat mencari informasi yang sekiranya tidak bisa ditemukan, mengikuti bimbingan belajar di suatu lembaga, dan lain sebagainya. Untuk kebutuhan motivasi berprestasi, keterampilan khusus juga dapat mempengaruhi dalam pencapaian mimpi para mahasiswa ini melalui kegiatan non akademis. Selain fasilitas dan keterampilan khusus, mereka juga mendapat pengaruh dari dalam diri, keluarga, dan masyarakat sekitarnya.

Masyarakat berperan penting dalam peningkatan prestasi siswa, orang tua dan teman sebaya pun juga berperan penting dalam hal tersebut.Tak hanya dorongan dari luar, dorongan dari dalam diri siswa tersebut juga yang dapat menggerakkan efektifitas belajar dan dapat mencari solusi dalam pemecahan masalah dan dapat mengatasi masalah tersebut sehingga meningkatkan kemampuan siswa agar ia dapat mencapai tujuan yang diinginkan. Untuk mendapatkan hal tersebut, motivasi dari dalam diri individu tersebut juga dapat mempengaruhi apakah individu tersebut mempunyai keinginan yang kuat atau tidak dalam mencapai apa yang diharapkan.

Seseorang yang memiliki motivasi berprestasi yang tinggi akan selalu bersemangat dan berambisi tinggi, melakukan tugas yang diberikan padanya dengan sebaik mungkin, belajar dengan lebih cepat, dan memiliki prestasi dalam bidang yang menjadi keahlian mereka (Santrock, 2007). Ketika memiliki beban tugas yang banyak, sulit, dan harus dikumpulkan dengan cepat, mereka akan mengerjakan tugas tersebut dengan keadaan terdesak sehingga individu tersebut merasa tertekan dan stres.

Banyak siswa yang hanya ingin cepat lulus dari masa SMA agar mereka dapat ke jenjang perkuliahan yang pengambilan jurusannya sesuai dengan apa yang mereka inginkan, tetapi mereka juga tidak memperhatikan aspek non akademis dimana nilai tersebut dapat menunjang mereka agar dapat mencapai yang diinginkan. Ketika guru menerangkan pelajaran di depan kelas, pada beberapa siswa yang hanya mendengarkan tetapi saat ditanya malah diam saja, ada yang sambil meemainkan handphone mereka, bahkan ketika disuruh mengerjakan tugas rumah malah dikerjakan keesokan harinya saat dikelas dan saat ada mata pelajaran yang bersangkutan. Hal tersebut dapat menghambat individu tersebut mencapai yang diinginkan dengan maksimal. Tetapi diantara siswa yang sedemikian rupa, ada siswa yang mengejar mimpinya dengan sungguh-sungguh sehingga mendapatkan hasil yang maksimal sesuai dengan keinginannya.

Hal inilah yang membuat nilai raport selama sekolah tidak meningkat. Dalam bidang non akademis pun demikian, dalam suatu acara organisasi sekolah diperlukan beberapa anggota yang dapat mengerjakan tugasnya dengan tanggung jawab, namun banyak dari bagian organisasi hanya santaisantai saja dan bersikap tidak mau repot sehingga mengambil pekerjaan yang ringan-ringan saja. Hal ini dapat membuat anggota yang lain merasa bingung dan dapat menghambat pelaksanaan yang sudah dibuat matang-matang karena kurangnya komunikasi dalam organisasi tersebut. Tidak hanya dalam organisasi sekolah, 
mengikuti ekstrakulikuler juga dapat meningkatnya aspek non akademis sehingga dapat melatih diri siswa untuk mencoba hal-hal yang baru, misalnya mengikuti ekstrakulikuler yang berhubungan dengan olahraga, mungkin saat diadakan turnamen persahabatan siswa dapat mengikuti hal tersebut dan mengetahui suasana yang ada disana.

Individu masih termasuk dalam masa remaja saat sekolah. Dimana dalam masa remaja, individu mengalami gejolak dalam diri karena merupakan masa peralihan dari masa anak-anak ke masa dewasa. Ketika mereka tidak dapat menyelesaikan suatu masalah, individu tersebut dapat lari dari masalah tersebut dengan cara yang tidak baik, misalnya ketika individu tersebut tidak mengerjakan tugas mata kuliah maka individu tersebut membolos saat perkuliahan tersebut, atau saat individu tersebut ialah seorang broken home mungkin saja ia akan menjadi anak yang nakal. Tetapi dari banyaknya kesuliatankesulitan tersebut, masih ada mahasiswa yang memilih untuk tetap mengerjakan tugasnya dengan penuh tanggung jawab dengan pilihan yang mereka pilih sebelumnya.

Mereka bila memiliki masalah malah lari ke hal-hal yang negatif seperti minum minuman keras, menjadi anak yang kecanduan narkoba, kabur dari rumah, dan sebagainya, sehingga mereka sulit untuk menyelesaikannya. Sedangkan kesulitankesulitan yang tak bisa ditangani oleh individu tersebut sangat berpengaruh dengan diri individu yang mengalaminya. Kesulitan inilah yang disebut self resiliensi, dimana kesulitan untuk bangkit kembali dari keadaan yang tidak menyenangkan hingga menjadi hal yang menyenangkan.

Menurut Reivich dan Shatte (2002), resiliensi adalah kapasitas untuk merespon secara sehat dan produktif ketika menghadapi kesulitan atau trauma, dimana hal itu penting untuk mengelola tekanan hidup sehari-hari. Berdasarkan Reivich dan
Shatte ada tujuh aspek dari resiliensi, yaitu pengendalian emosi, kemampuan untuk mengontrol impuls, optimis, kemampuan untuk menganalisis penyebab dari masalah, kemampuan untuk berempati, self efficacy, dan kemampuan untuk meraih apa yang diinginkan.

Elizabert B Hurlock (1973) memberi batasan masa remaja berdasarkan usia kronologis, yaitu antara 13 hingga 18 tahun. Pada usia tersebut, remaja mengalami gejolak dalam diri mereka dimana pencarian jati diri sangat penting di usia mereka. Jati diri tersebut yang nantinya akan menuntun kemana mereka akan berkembang dan menjadi diri sendiri tanpa melihat orang lain. Disini juga mereka mencoba untuk mengatasi masalahnya sendiri dan ketika masalah itu terselesaikan, maka hal tersebut akan menjadi pengalaman yang baik bagi mereka ketika mendapat masalah yang sama. Mereka juga belajar akan tanggung jawab, sehingga mereka dapat menjunjung rasa tanggung jawab tersebut.

Resiliensi sendiri adalah kemampuan untuk mengatasi dan beradaptasi terhadap kejadian yang berat atau masalah yang terjadi dalam kehidupan. Sehingga beberapa siswa merasa tak mampu dan memutuskan untuk lari ke hal-hal yang negatif seperti narkoba, miras, dan mengikuti pergaulan bebas karena tidak mampu mengerjakan tugas di sekolah yang memerlukan tuntutan tinggi maupun dari banyak kasus negatif dari luar sekolah yang telah ia lakukan. Tetapi banyak juga siswa yang memilih untuk bertahan dengan mengerjakan tugas apa yang telah diberikan dan menghiraukan pandangan orang lain sehingga ia dapat lulus dari sekolahnya tersebut.

Seperti penelitian yang ditulis oleh Tria Septiani dan Nurindah Fitria (2016) bahwa terdapat hubungan signifikan yang negatif untuk setiap dimensi variabel resiliensi dengan dimensi stresor. Dimana bila variabel resiliensi tinggi, maka belum tentu 
dimensi-dimensi yang lain akan tinggi juga, mungkin bisa turun dan bisa naik.

Remaja saat ini bila memiliki masalah, masih suka tidak bisa melupakan masalah yang telah terjadi dan bangkit kembali yang biasa kita kenal dengan istilah "gagal MoveOn". Gagal move-on inilah yang dapat menghambat kita untuk maju ke depan dengan prestasi yang membanggakan. Karena untuk mendapatkan prestasi yang membanggakan membutuhkan motivasi berprestasi. Jika terus menerus tidak aja kemajuan, hal tersebut dapat menurunkan motivasi untuk berprestasi dari dalam diri individu tersebut. Paskibraka adalah kepanjangan dari Pasukan Pengibar Bendera Pusaka dengan tugas utamanya mengibarkan duplikat bendera pusaka dalam upacara peringatan "Proklamasi Kemerdekaan Indonesia" di 3 tempat, yakni tingkat Kabupaten/Kota (Kantor Bupati/Wali Kota), Provinsi (Kantor Gubernur), dan Nasional (Istana Merdeka). Menurut salah satu guru di SMAI Malang, masuk menjadi anggota Paskibraka harus melalui seleksi yang ketat dilihat dari nilai rapor, keaktifan organisasi, sikap selama di sekolah serta tinggi badan yang mencukupi untuk dikirim menjadi wakil sekolah untuk menjadi anggota Paskibraka. Salah satu anggota Paskibraka di SMAI Malang berpendapat bahwa bisa menjadi anggota Paskibraka merupakan suatu kebanggaan tersendiri karena dapat melalui seleksi yang begitu ketat dan mereka dilatih baik secara fisik dan mental. Hal inilah yang mendorong para anggota Paskibraka untuk menyesuaikan diri dengan segala peraturan dan kegiatan serta bisa membagi waktu antara kegiatan Paskibraka dan sekolah supaya tetap dapat berprestasi, karena mereka menjadi contoh bagi siswa lain.

\section{Definisi Motivasi Berprestasi}

Motivasi menurut Carole Wade dan Carol Tavris (2007) adalah suatu proses dalam diri manusia atau hewan yang menyebabkan organisme tersebut bergerak menuju tujuan yang dimiliki, atau bergerak menjauh dari situasi yang tidak menyenangkan.

Menurut David C. McClelland (1987), motivasi berprestasi atau yang biasa kita kenal dengan need for achievement yaitu dorongan untuk melebihi, mencapai standar-standar, berusaha keras untuk berhasil. Orang yang memiliki kebutuhan berprestasi yang tinggi akan menyukai tantangan dan ingin meningkatkan prestasi agar selalu unggul.

Motivasi berprestasi diartikan sebagai sesuatu yang ada sejak lahir yang ditumbuhkan dan dikembangkan melalui interaksi dan lingkungan (Gunarsa, 2003)

\section{Ciri-ciri Motivasi Berprestasi}

Djaali (2007) menyimpulkan dari Johnson dan Schwitzgebel \& Kalb mengenai beberapa karakteristik individu dengan motivasi berprestasi tinggi, antara lain:

a. Menyukai situasi atau tugas yang memikul tanggung jawab pribadi atas hasil-hasilnya dan bukan atas dasar keberuntungan, nasib, atau kebetulan.

b. Memilih tujuan yang realistis tetapi menantang dari tujuan yang terlalu mudah dicapai atau terlalu besar resikonya.

c. Mencari situasi atau pekerjaan di mana ia memperoleh umpan balik dengan segera dan nyata untuk menentukan baik atau tidaknya hasil pekerjaanya.

d. Senang bekerja

e. Sendiri dan bersaing untuk mengungguli orang lain.

f. Mampu menangguhkan pemuasan keinginannya demi masa depan yang lebih baik.

g. Tidak tergugah untuk sekedar mendapatkan uang, status, atau keuntungan lainnya, ia akan mencarinya apabila hal-hal tersebut merupakan lambang prestasi, suatu ukuran keberhasilan. 


\section{Aspek Motivasi Berprestasi}

Menurt Mc Clelland, motivasi berprestasi memiliki aspek-aspek berikut :

a. Tanggung jawab

Seseorang yang motivasi berprestasinya tinggi akan lebih bertanggung jawab dengan tugas yang telah diberika kepada dirinya dan akan berusaha menyelesaikannya. Begitupun sebaliknya, bila individu tersebut motivasi berprestasinya rendah maka individu tersebut memiliki tanggung jawab yang kurang pada tugas-tugas yang telah diberikan.

b. Mempertimbangkan resiko pemilihan tugas

Individu yang motivasi berprestasinya tinggi cenderung mempertimbangkan dahulu resiko dari pekerjaan yang akan dihadapi sebelum memulainya. Individu tersebut akan memilih dan menyukai permasalahan yang tingkat kesukarannya sedang dan menantang dan memungkinkan untuk diselesaikan. Sedangkan individu yang memiliki motivasi berprestasi rendah justru akan menganbil tugas yang pengerjaannya sangat mudah agar ia dapat mengerjakannya dengan baik.

c. Memperhatikan umpan balik

Mereka yang motivasi berprestasinya tinggi akan sangat menyukai umpan balik atas apa yang telah ia kerjakan karena menganggap hal tersebut sangat berguna sebagai perbaikan agar lebih baik lagi kedepannya. Dan individu yang motivasi berprestasinya rendah tidak menyukai adanya umpan balik karena akan menunjukkan kesalahan-kesalahan yang telah dia lakukan dan kemungkinan kesalahan tersebut diulang kembali dikemudian hari.

d. Kreatif dan inovatif

Jika memiliki motivasi berprestasi yang tinggi, individu akan mencari cara baru dalam mengerjakan tugasnya agar efektif dan seefisien mungkin, dan individu tersebut tidak menyukai pekerjaan yang sama dari waktu ke waktu. Sedangkan jika memiliki motivasi berprestasi yang rendah individu tersebut akan menyukai pekerjaan yang sifatnya rutinitas karena dengan hal tersebut tidak susah dikerjakan dan tidak memerlukan hal yang baru.

e. Waktu penyelesaian tugas

Individu yang motivasi berprestasinya tinggi akan mencoba untuk menyelesaikan tugas yang diberikan dalam waktu yang singkat dan tidak membuang-buang waktu yang ada. Sedangkan individu yang memiliki motivasi berprestasi rendah kurang tertantang untuk menyelesaikan tugasnya dengan cepat sehingga cenderung memakan waktu yang lama, suka menunda-nunda dan tidak efisien.

f. Keinginan menjadi yang terbaik

Jika individu memiliki motivasi berprestasi yang tinggi, ia akan menunjukkan hasil kerja yang sebaikbaiknya agar mendapat predikat terbaik dan perilaku mereka berorientasi pada masa yang akan datang. Dan yang memiliki motivasi berprestasinya rendah tidak memikirkan mendapat predikat terbaik dan tidak berusaha untuk meningkatkan penyelesaian tugas semaksimal mungkin.

g. Mengadakan Antisipasi

Melakukan kegiatan yang dapat menghindari kegagalan atau kesulitan yang mungkin terjadi.

\section{Faktor Motivasi Berprestasi}

Motivasi berprestasi merupakan proses psikologi yang memiliki arah dan tujuan agar kelak berhasil dengan baik dikemudian hari. Menurut Mc Clelland ada beberapa faktor yang dapat mempengaruhi motivasi berprestasi seseorang, antara lain :

a. Pengalaman pada tahun-tahun pertama kehidupan

Pengalaman yang berbeda dari masa lalu tiap-tiap orang adalah penyebab 
terjadinya variasi tinggi rendahnya kecenderungan untuk berprestasi pada individu.

b. Latar belakang budaya tempat seseorang dibesarkan

Budaya juga dapat mempengaruhi motivasi berprestasi. Bila individu tinggal di lingkungan yang menekankan pada keuletan, kerja keras, sikap inisiatif dan kompetitif serta suasana yang dapat membuat individu mencoba untuk memecahkan masalah sendiri tanpa takut untuk gagal, maka inividu tersebut dengan sendirinya akan berkembang dan memiliki hasrat prestasi yang tinggi.

c. Peniruan tingkah laku (modeling)

Dengan modeling, anak mengambil atau meniru banyak karakteristik dari apa yang telah dicontohkan, dan dalam kebutuhan untuk berprestasi sekalipun.

d. Lingkungan tempat proses pembelajaran berlangsung

Menciptakan iklim yang menyenangkan, tidak mengancam, memberi semangat dan membangun sikap optimisme dalam belajar mampu mendorong seseorang agar tertarik untuk belajar, dan meningkatkan toleransi dalam kompetisi dan tidak mudah khawatir untuk gagal.

e. Harapan orang tua terhadap anaknya

Harapan orang tua untuk anaknya dalam meraih apa yang diinginkan dengan bekerja keras dan selalu berjuang akan mendorong anak untuk mencapai prestasi yang diinginkan.

Sedangkan menurut Djaali (2008) bahwa faktor yang mempengaruhi motivasi berprestasi adalah:

a. Faktor Intrinsik

Merupakan faktor yang berasal dari dalam diri individu. Faktor intrinsik initerdiri dari tujuan yang ditetapkan, harapan yang diinginkan, cita-cita, harga diriyang tinggi, rasa takut untuk sukses, dan potensi dasar yang dimiliki.

b. Faktor Ekstrinsik

Merupakan faktor yang berasal dari luar diri individu atau lingkungan.Faktor ekstrinsik ini terdiri dari faktor situasional, norma kelompok, resiko yangditimbulkan sebagai akibat dari prestasi yang diperoleh, sikap terhadap kehidupandan lingkungan,serta pengalaman yang dimiliki.

\section{Definisi Resiliensi}

Secara etimologis resiliensi diadaptasi dari kata dalam Bahasa Inggris resilience yang berarti daya lenting atau kemampuan untuk kembali dalam bentuk semula (Poerwadarminta, 1982).Resiliensi menurut Reivich dan Shatte(2002) adalah kapasitas untuk merespon secara sehat dan produktif ketika menghadapi kesulitan atau trauma, dimana hal itu penting untuk mengelola tekanan hidup seharihari.Grotberg (dalam Schoon, 2006) menyatakan bahwaresiliensi adalah kemampuan seseorang untuk menilai, mengatasi, dan meningkatkan diri ataupun mengubah dirinya dariketerpurukan atau kesengsaraan dalam hidup.

Menurut Jackson (2002) resiliensi adalah kemampuan individu untuk dapat beradaptasi dengan baik meskipun dihadapkan dengan keadaan yang sulit. Dalam ilmu perkembangan manusia, resiliensi memilki makna yang luas dan beragam, mencakup kepulihan dari masa traumatis, mengatasi kegagalan dalam hidup, dan menahan stres agar dapat berfungsi dengan baik dalam mengerjakan tugas sehari-hari.

Sedangkan Connor dan Davidson (2003) resiliensi merupakan kualitas seseorang dalam hal kemampuan untuk menghadapi penderitaan. Dan Grotberg (2000) menyatakan bahwa resiliensi adalah kemampuan seseorang untuk menilai, mengatasi, dan meningkatkan diri ataupun mengubah dirinya dari keterpurukan atau kesengsaraan dalam hidup, karena setiap orang pasti mengalami kesulitan ataupun sebuah masalah dan tidak ada seseorang yang hidup di dunia tanpa suatu masalah atau kesulitan. 


\section{Aspek Resiliensi}

Menurut Reivich dan Shatte 2002 (dalam Abdul, 2017) ada 7 aspek dalam membentuk resiliensi, yaitu :

a. Pengendalian emosi

Pengendalian emosi adalah suatu kemampuan untuk tetap tentang meskipun berada dibawah tekanan. Individu yang mempunyai resiliensi yang baik, menggunakan kemampuan positif untukn membantu mengontrol emosi, memutuskan perhatian dan prilaku. Mengespresikan emosi dengan tepat adalah bagianresiliensi. Individu yang tidak resilient cendrung lebih mengalami kecemasan, kesedihan dan kemarahandibandingkan dengan individu lain, dan mengalami saat nyang berat untuk mendapatkan kembali kontrol diri ke4tika mengalami kekecewaan.

b. Kemampuan untuk mengontol impuls

Kemampuan untuk mengatur implus berhubungan dengan pengendalian emosi. Individu yang kuat mengontrol implusnya cendrung mampu mengendalikan emosinya.

c. Optimis

Individu dengan resiliensi yang baik adalah individu yang optimis, yang percaya bahwa segala sesuatu dapat berubah menjadi lebih baik. Individu mempunyai harapan akan masa depan dan dapat mengontrol arah kehidupannya. Optimis membuat fisik menjadi lebih sehat dan tidak mudah mengalami depresi.

d. Kemampuan untuk menganalisis penyebab dari masalah

Individu dengan resiliensi yang baik sebagian besar memiliki kemampuan menyesuaikan diri secara kognitif dan dapat mengenali semua penyebab yang cukup berarti dalam kesulitan yang dihadapi. individu tidak secara refleks menyalahkan orang lain untuk menjaga self esteem-nya atau membebaskan dirinya dari rasa bersalah.

e. Kemampuan untuk berempati

Beberapa individu mahir dalam menginterpretasikan apa yang para ahli psikologi katakan sebagai bahasa non verbal dari orang lain, seperti ekspresi wajah, nada suara, bahasa tubuh, dan menentukan apa yang orang lain pikirkan dan rasakan. Walaupun individu tidak mampu menempatkan dirinya dalam posisi orang lain, namun mampu untuk memperkirakan apa yang orang rasakan, dan memprediksi apa yang mungkin dilakukan oleh orang lain. Dalam hubungan interpersonal, kemampuan untuk membaca tanda-tanda non-verbal menguntungkan, dimana orang membutuhkan untuk merasakan dan dimengerti orang lain.

f. Self efficacy

Self efficacy adalah keyakinan bahwa individu dapat menyelesaikan masalah, mungkin melalui pengalaman dan keyakinan akan kemampuan untuk berhasil dalam kehidupan. Self efficacy membuat individu lebih efektif dalam kehidupan. Individu yang tidak yakin dengan efficacy-nya bagaikan kehilangan jati dirinya, dan secara tidak sengaja memunculkan keraguan dirinya.

g. Kemampuan untuk meraih apa yang diinginkan

Resiliensi membuat individu mampu meningkatkan aspek-aspek positif dalam kehidupan. Resiliensi adalah sumber dari kemampuan untuk meraih. Beberapa orang takut untuk meraih sesuatu, karena berdasarkan pengalaman sebelumnya, bagaimanapun juga, keadaan menyulitkan akan selalu dihindari.

Menurut Jackson dan Watkin (2004) memaparkan tujuh kemampuan yang membentuk resiliensi, yaitu sebagai berikut:

a. Pengaturan emosi (emotion regulation). Pengaturan emosi adalah kemampuan 
untuk tetap tenang di bawah kondisi yang menekan,

b. Pengendalian gerak (impulse control). Pengendalian gerak adalah kemampuan Individu untuk mengendalikan keinginan, dorongan, kesukaan, serta tekanan yang muncul dari dalam diri,

c. Optimisme (realistic optimism). Individu yang resilien adalah individu yang optimis, optimisme adalah ketika kita yakin bahwa masa depan kita akan lebih baik.

d. Kemampuan menganalisis masalah (Causal Analysis). Causal analysis merujuk pada kemampuan individu untuk mengidentifikasikan secara akurat penyebab dari permasalahan yang mereka hadapi.

e. Empati (Emphaty). Empati sangat erat kaitannya dengan kemampuan individu untuk membaca tanda-tanda kondisi emosional dan psikologis orang lain.

f. Efikasi diri (Self-efficacy). Self-efficacy adalah hasil dari pemecahan masalah yang berhasil. Self-efficacy merepresentasikan sebuah keyakinan untuk mampu memecahkan masalah yang kita alami dan mencapai kesuksesan.

g. Pencapaian (Reaching out), adalah pencapaian individu dalam meraih sesuatu.

\section{Faktor Resiliensi}

Menurut Resnick, dkk (2011), terdapat empat faktor yang mempengaruhi resiliensi pada individu, antara lain:

a. Self-esteem

Jika individu memiliki self-esteem yang baik akan dapat membantu individu tersebut menghadapi masalah yang terjadi.

b. Dukungan sosial

Dukungan sosial sering dihubungkan dengan resiliensibagi mereka yang mengalami kesulitan dan kesengsaraan akan meningkatkan resiliensidalam dirinya ketika pelaku sosial yang ada disekelilingnya memiliki supportterhadap penyelesaian masalah atau proses bangkit kembali yang dilakukan oleh individu tersebut.

c. Spiritualitas

Dalam hal ini pandangan spiritual pada individu percaya bahwa Tuhan adalah penolong dalam setiap kesengsaraan yang tengah dialaminya, tidak hanya manusia yang mampu menyelesaikan segala kesengsaraan yang ada, dan dalam proses ini individu percaya bahwa Tuhan adalah penolong bagi setiap hambanya.

d. Emosi positif

Emosi positif juga merupakan faktor penting dalam pembentukan resiliensi individu. Emosi positif sangat dibutuhkan ketika menghadapi suatu situasi yang kritis dan dengan emosi positif dapat mengurangi stres secara lebih efektif. Individu yang memiliki rasa syukur mampu mengendalikan emosi negatif dalam menghadapi segala permasalahan di dalam kehidupan.

\section{METODE PENELITIAN}

Penelitian ini menggunakan metode kuantitatif, untuk mengungkapkan apakah ada hubungan antara resiliensi dan need for achievement pada regu Paskibraka di SMA Islam Malang. Populasi dalam penelitian ini berjumlah 50 siswa sehingga dalam pengambilan sampelnya menggunakan teknik studi populasi, seperti yang dinyatakan oleh Sabar (2009) apabila seseorang ingin meneliti semua elemen yang ada dalam wilayah penelitian, maka penelitiannya merupakan penelitian populasi atau studi populasi. Teknik analisis yang digunakan adalah korelasi Product Moment yang dikemukakan oleh Pearson dengan bantuan program IBM SPSS Statistics version 20 for Windows.

\section{HASIL}

\section{a. Uji Normalitas}

Tabel 1.

Uji Normalitas

One-Sample Kolmogorov-Smirnov Test 


\begin{tabular}{|c|c|c|c|}
\hline & & $\begin{array}{l}\text { VAR0000 } \\
1\end{array}$ & $\begin{array}{l}\text { VAR00 } \\
002\end{array}$ \\
\hline \multirow[t]{2}{*}{$\mathrm{N}$} & & 50 & 50 \\
\hline & Mean & 158.54 & 145.90 \\
\hline \multirow{2}{*}{$\begin{array}{l}\text { Normal } \\
\text { Parameters }\end{array}$} & Std. & & \\
\hline & $\begin{array}{l}\text { Deviatio } \\
\mathrm{n}\end{array}$ & 12.144 & 12.614 \\
\hline \multirow{2}{*}{$\begin{array}{l}\text { Most Extreme } \\
\text { Differences }\end{array}$} & Absolute & .103 & .145 \\
\hline & $\begin{array}{l}\text { Positive } \\
\text { Negative }\end{array}$ & $\begin{array}{l}.084 \\
-.103\end{array}$ & $\begin{array}{l}.140 \\
-.145\end{array}$ \\
\hline \multicolumn{2}{|c|}{ Kolmogorov-Smirnov Z } & .730 & 1.023 \\
\hline \multicolumn{2}{|c|}{ Asymp. Sig. (2-tailed) } & .660 & .246 \\
\hline \multicolumn{4}{|c|}{ a. Test distribution is Normal. } \\
\hline \multicolumn{4}{|c|}{ b. Calculated from data. } \\
\hline
\end{tabular}

Berdasarkan hasil uji normalitas dapat diketahui jika nilai perhitungan yang dilakukan ternyata harga KolmogorovSmirnov $Z$ yang diperoleh variabel $\mathrm{x}$ adalah 0,660 dan harga $p$ atau Asymp. sig (2-tailed) $=0,660$. Karena harga $\mathrm{p}=0,660>0,05$ maka distribusi skornya normal. Dan untuk variabel y adalah 0,246 dan harga $\mathrm{p}$ atau Asymp. sig (2-tailed) $=0,246$. Karena harga $\mathrm{p}=0,246>0,05$ maka distribusi skornya normal.

\section{b. Uji Linieritas}

Tabel 2

Uji linieritas Need for Achievement dan Resiliensi

\begin{tabular}{|c|c|c|c|c|c|c|c|}
\hline & & & $\begin{array}{l}\text { Sum } \\
\text { of } \\
\text { Squar } \\
\text { es }\end{array}$ & $\begin{array}{l}d \\
f\end{array}$ & $\begin{array}{l}\text { Mea } \\
\mathrm{n} \\
\text { Squa } \\
\text { re }\end{array}$ & $\mathrm{F}$ & $\begin{array}{l}\mathrm{Si} \\
\mathrm{g} .\end{array}$ \\
\hline \multirow{12}{*}{$\begin{array}{l}\text { VAR0 } \\
0001 * \\
\text { VAR0 } \\
0002\end{array}$} & \multirow{4}{*}{$\begin{array}{l}\text { Betw } \\
\text { een }\end{array}$} & (Combi & 3632. & 2 & 165. & 1.2 & .2 \\
\hline & & ned) & 980 & 2 & 135 & 41 & 94 \\
\hline & & Linearit & 148.8 & & 148. & 1.1 & .3 \\
\hline & & $\mathrm{y}$ & 58 & 1 & 858 & 18 & 00 \\
\hline & \multirow{3}{*}{$\begin{array}{l}\text { urou } \\
\text { ps }\end{array}$} & Deviati & & & & & \\
\hline & & on from & 3484. & 2 & 165. & \multirow{3}{*}{$\begin{array}{l}1.2 \\
47\end{array}$} & .2 \\
\hline & & Linearit & 121 & 1 & 911 & & 91 \\
\hline & & $\mathrm{y}$ & & & & & \\
\hline & \multirow{2}{*}{\multicolumn{2}{|c|}{ Within Groups }} & 3593. & 2 & 133. & & \\
\hline & & & 440 & 7 & 090 & & \\
\hline & \multirow{2}{*}{\multicolumn{2}{|c|}{ Total }} & 7226. & 4 & & & \\
\hline & & & 420 & 9 & & & \\
\hline
\end{tabular}

Diketahui dari data tersebut, didapatkan hasil $\mathrm{p}=0,300$. Dari hasil tersebut dapat dilihat bahwa signifikansi lebih dari dari $0,05(0,300>0,05)$ maka dapat disimpulkan bahwa antara variabel bebas dengan variabel terikat terdapat hubungan yang linear. Berdasarkan uji linearitas yang dilakukan dapat disimpulkan bahwa asumsi linear dalam penelitian ini terpenuhi.

\section{c. Uji Hipotesis}

Tabel 3

Koefisien Korelasi Resiliensi dan Need for Achievement

\begin{tabular}{|c|c|c|c|}
\hline & & VAR00001 & VAR00002 \\
\hline \multirow{3}{*}{ VAR00001 } & $\begin{array}{l}\text { Pearson } \\
\text { Correlation }\end{array}$ & 1 & -.144 \\
\hline & $\begin{array}{l}\text { Sig. } \\
\text { tailed) }\end{array}$ & & .320 \\
\hline & $\mathrm{N}$ & 50 & 50 \\
\hline \multirow{3}{*}{ VAR00002 } & $\begin{array}{l}\text { Pearson } \\
\text { Correlation }\end{array}$ & -.144 & 1 \\
\hline & $\begin{array}{l}\text { Sig. } \\
\text { tailed) }\end{array}$ & .320 & \\
\hline & $\mathrm{N}$ & 50 & 50 \\
\hline
\end{tabular}

Dari hasil uji korelasi diatas dapat diketahui hasil signifikansi $-0,144<0,05$, yang artinya tidak ada korelasi atau hubungan antara variabel $X$ dengan variabel Y. Artinya tidak ada hubungan antara resiliensi dengan need for achievement pada Regu Paskibra di SMA Islam Malang, dengan demikian hipotesa ditolak.

\section{PEMBAHASAN}

Berdasarkan hasil penelitian yang telah dilakukan, tidak ada hubungan yang signifikan antara resiliensi dengan need for achievement pada regu Paskibra di SMA Islam Malang, hal ini terjadi karena dipengaruhi oleh faktor yang lain dan siswa di SMA Islam Malang banyak yang mengikuti ekstrakurikuler dan banyak siswa yang memilih lebih dari 1 jenis ekstrakurikuler, sehingga waktu mereka banyak tercurah untuk tugas sekolah dan ekstrakurikuler.

Ketika mereka memiliki permasalahan, mereka kurang fokus dalam pemecahan 
masalahnya, mereka juga kurang fokus dalam mencapai kebutuhannya atau keinginan untuk berprestasi. Karena dengan nilai tidak memuaskan, yang penting bagi mereka semua tugas telah selesai.

Faktor lain yang bisa mempengaruhi motivasi berprestasi bisa karena kebiasaan belajar, hal ini didukung oleh penelitian yang ditulis oleh Jurni Kumaat pada tahun 2017 dengan judul "Hubungan Kebisaan Belajar dengan Motivasi Berprestasi Siswa SMA Negeri 1 Motoling" yang menyatakan bahwa ada hubungan antara kebiasaan belajar dengan motivasi berprestasi. Dengan hasil perhitungan analisis korelasi sederhana dengan menggunakan komputasi, dan setelah dianalisis dengan teknik analisis korelasi product moment diperoleh koefisien korelasi empirik (rxy) sebesar $=$ 0.771 . Nilai koefisien korelasi teoritik pada taraf signifikan 5\% dk 102 adalah 0.195. Membandingkan harga rxy empirik dengan harga rxy teoritik diketahui bahwa harga rxy empirik lebih besar dari harga rxy teoritik atau $0.771>0.195$. Hasil ini dapat disimpulkan bahwa terdapat hubungan antara kebiasaan belajar dengan motivasi berprestasi pada siswa SMA Negeri 1 Motoling Kabupaten Minahasa Selatan.

Selain kebiasaan belajar, efikasi diri juga bisa mempengaruhi motivasi berprestasi sesuai dengan penelitian yang ditulis oleh Firdaningsih pada tahun 2016 dengan judul "Efikasi Diri dan Motivasi Berprestasi dalam Meningkatkan Hasil Belajar Sejarah". Dari hasil perhitungan didapatkan koefisien jalur pengaruh langsung efikasi diri terhadap hasil belajar sejarah $(\mathrm{p} 31)=0,313$. Sementara, hasil uji signifikansi koefisien korelasi diatas diperoleh nilai thitung sebesar 5,909, sedangkan nilai $\mathrm{t}$ tabel untuk $\mathrm{dk}=105$ pada $\alpha=0,01$ adalah 2,623. Nilai thitung $>$ t tabel, sehingga dapat disimpulkan bahwa koefisien jalur efikasi diri terhadap hasil belajar sejarah adalah sangat signifikan. Ini berarti hipotesis: "Efikasi diri berpengaruh langsung terhadap hasil belajar sejarah", diterima.

\section{KESIMPULAN}

Kesimpulan dari penelitian ini adalah bahwa tidak ada hubungan yang signifikan antara Resiliensi dan Need for Achievement atau motivasi berprestasi. Karena pada periode masa remaja, individu mulai mengalami gejolak-gejolak dalam diri yang mengharuskan mereka meninggalkan tingkah laku pada masa kanak-kanak. Remaja juga harus dapat menyesuaikan diri secara mental dalam menghadapi suatu masalah fisik dan sosial. Karena kurangnya pengalaman dalam mengatasi masalah, mereka tidak dapat mengatasi masalahnya dengan baik sehingga mereka "gagal moveon" atau tidak bisa bangkit kembali untuk menyelesaikan masalahnya tersebut. Kegagalan yang tidak dapat mereka selesaikan inilah yang memerlukan perhatian khusus agar dapat memotivasi diri untuk berprestasi dengan maksimal. Dengan demikian hipotesa ditolak.

\section{SARAN}

Saran yang dapat diberikan bagi siswa, bila mendapat suatu masalah diharap segera mencari solusi dan jika tidak bisa menyelesaikan sendiri, dapat sharing dengan teman. Berikutnya adalah belajar mengatur waktu, dan jadikanlah belajar sebagai suatu kebiasaan atau kebutuhan sehingga mampu meningkatkan motivasi berprestasi. Sedangkan untuk pihak sekolah, diharapkan penelitian ini dapat digunakan sebagai bahan pertimbangan dalam usaha peningkatan resiliensi bagi siswa dengan cara memberikan bimbingan dan penyuluhan bagaimana menyiasati permasalahan. Kemudian frekuensi pengadaan lomba-lomba ditingkatkan untuk memicu need for achievement siswa. Dan untuk peneliti selanjutnya diharapkan dapat mengembangkan penelitian resiliensi terhadap need for achievement pada siswa 
SMA yang lebih spesifik dan agar dapat bermanfaat di kemudian hari.

\section{DAFTAR PUSTAKA}

Amelia Serti , Asni Enikarmila \& Chairilsyah Daviq. 2014. Gambaran Ketangguhan Diri (Resiliensi) pada Mahasiswa Tahun Pertama Fakukltas Kedokteran Universitas Riau. Jurnal Fakultas Kedokteran . No.2, Vol.1

Bordaes Febrianurdi Andreas, Elya Kurniawan Jimmy. Hubungan Motivasi Berprestasi dengan Minat Berwirausaha Mahasiswa Psikologi. Jurnal Psikologi.

Connor, Kathryn M, Jonathan R.T Davidson.2003.Development of $A \mathrm{New}$ Resilience Scale:The connor-Davidson Resilience Scale (CD-RISC).Research Article

Djarwanto, Pangestu Subagyo. 1996. Statistik Induktif.Yogyakarta:BPFEYogyakarta

Dwi UlfaWahyi. 2016. Resiliensi pada Mahasiswa yang Memiliki OrangTua Tunggal. Skripsi Fakultas Ilmu Pendidikan.

Dwi Mayangsari Marina. 2013. Motivasi Berprestasi Mahasiswa ditinjau dari Penerimaan Orangtua. Jurnal Ecopsy No.1.Vol.1.

Fauzia Ellya. 2013. Pengaruh prestasi Belajar dan Motivasi Berprestasi terhadap kesiapan Berwirausaha pada Siswa SMK Negri 1 CERME Gresik. No. 1. Vol.1.

Firdaningsih.2016.Efikasi Diri dan Motivasi Berprestasi dalam Meningkatkan Hasil Belajar Sejarah.Jurnal Penelitian dan Penilaian Pendidikan.Vol 1.Nomor 1.

Haryadi, Sarjono, Winda Julianita. 2011. SPSS vs LISREL. Jakarta.Salemba Empat.
Hurlock, Elizabeth B.1980.Psikologi Perkembangan, Suatu Pendekatan Sepanjang Rentang Kehidupan. Jakarta. Penerbit Erlangga. Edisi kelima.

Kuumaat,Jurni.2017.Hubungan Kebiasaan Belajar dengan Motivasi Berprestasi Siswa SMA Negeri 1 Motoling.Jurnal Forum Pendidikan.Vol 13.Nomer 2.

Mardiana Tri, Daviq Chairilsyah, Devi Risma. Hubungan Antara Self Resiliensi dengan Berprestasi Mahasiswa PG PAUD Angkatan 2015 Fakultas Keguruan dan Ilmu Pendidikan Universitas Riau. Jurnal.

Septiani Tria, Fitria Nurindah. 2016. Hubungan Antara Resiliensi dengan Stres pada Mahasiswa Sekolah Tinggi Kedinasan. Jurnal Penelitian Psikologi. No. 2, Vol.07.

Sugiono. 2017. Metode Penelitian Pendidikan. Bandung: CV Alfabeta.

Rahim, Abdul A. 2017. Hubungan Antara Resiliensi Dengan Motivasi Belajar (Pada Siswa Sekolah Menengah Atas Negeri 1 Long Ikis). Ejournal. psikologi.fisip.

Ruswahyuningsih, M.C, Tina Afiatin.2015.Resiliensi pada Remaja Jawa.Gajah Mada Journal of Psycology.Volume 1, no. 2

Yeniar, Cantika Pasudewi.2013.Resiliensi pada Remaja Binaan Bapas Ditinjau dari Coping Stress.Skripsi.

http://kuliah-oti.blogspot.com /2015/11/t ahap-perkembangan-elizabeth-b-hurlock. html (diunduh tanggal 23 juni 2018)

http://mangihot.blogspot.com/2016/10/ pengertian-motivasi-berprestasimenurut.html (diunduh tanggal 23 juni 2018) 
http://www.sarjanaku.com/2012/11/pengert ian-resiliensi-definisi-konsep.html (diunduh tanggal 24 juni 2018)

http://repository.uin-suska.ac.id/6998/ 3/ BAB\%20II.pdf (diunduh tanggal 23 juni 2018)

http://ewintribengkulu.blogspot.com/2013/ 05/pengertian-resiliensi.html (diunduh tanggal 24 juni 2018)

http://www.landasanteori.com/2015/09/pen gertian-resiliensi-definisi-faktor.html (diunduh tanggal 25 juni 2018)

https://www.eurekapendidikan.com/2015/0 9/pengertian-dan-jenis-jenis-variabelpenelitian-evaluasi.html (diambil tanggal 1 juli 2018)

http://etheses.uin-malang.ac.id/1837/8/094 10019 Bab_3.pdf (diambil tanggal 17 juli 2018)
http://eprints.ums.ac.id/22299/13/LAMPIR AN.pdf(oleh Alalu Khairatun, 2012 diambil pada 20-7-2018)

http://belajarpsikologi.com/pengertianharga-diri/(tahun 2013, diambil pada 247-2018)

https://www.kajianpustaka.com/2017/12/pe ngertian-bentuk-dan-manfaat-dukungansosial.html (oleh Muchlisin Riadi, 7-122017 dan diambil pasa 24-7-2018)

http://www.landasanteori.com/2015/09/pen gertian-spiritualitas-definisi.html (diambil pada 24-7-2018)

http://artidukungansosial.blogspot.com/201 1/02/teori-dukungan-sosial.html

(oleh Kartika Sari, 25 Februari 2011. Diambil pada 18 Agustus 2018) 